\title{
Evaluation of surface coating and shrink- wrap packaging on shelf life and quality of mango cultivar 'Neelum'
}

\author{
Saji Gomez*, Sharon Jacob, Meagle Joseph, Dhanya Johnson \& Karishma Sebastian \\ Department of Post Harvest Technology, College of Agriculture, Kerala Agricultural University, Vellanikkara, Thrissur 680 656, Kerala, India \\ *Email: saji.gomez@kau.in
}

\section{ARTICLE HISTORY}

Received: 06 April 2021

Accepted: 24 May 2021

Available online: 01 July 2021

\section{KEYWORDS}

Mango cv. 'Neelum'

Nipro Fresh

Shrink-wrap packaging

Shelf life

Quality

\begin{abstract}
Kerala, the Indian state has the distinction of producing the earliest mangoes in the country, in February and the season extends up to May, coinciding with South West monsoon. Mango cultivar 'Neelum', the last commercial variety to attain maturity in the State is hampered by the incidence of fruit fly and anthracnose disease. An attempt was made during 2019-20 to extend the availability of the fruits of this cultivar by giving a surface coating with 'Nipro Fresh' wax containing the fungicide, Carbendazim, followed by shrink-wrap packaging in trays made of areca nut leaf sheath, before sanitizing with chlorine (100 ppm) and alum solution (1\%). Surface coating with 'Nipro Fresh', followed by shrink-wrap packaging of trays containing mangoes, and their subsequent storage in cool chamber at $12-13{ }^{\circ} \mathrm{C}$ and $85-90 \%$ relative humidity, extended the shelf life by 54 days, compared to the uncoated and unwrapped samples which had a shelf life of 9 days under ambient conditions. Respiration rate, physiological loss in weight, total soluble solids and carotenoids showed a steady rise while titratable acidity, total phenols and ascorbic acid recorded a declining trend.
\end{abstract}

\section{Introduction}

Mango, the national fruit of India, ranks third in terms of area and production in the state of Kerala. It is cultivated in an area of 79496 hectares with a production of 420048 tonnes (1). The fruit is a good source of carotenoids, ascorbic acid, phenols and dietary fibre. Mango varieties grown in Kerala start attaining maturity as early as February, which is the earliest in the country and the season extends up to May in the State. The variety 'Neelum', regarded as one of the choicest varieties of India, is a late season variety in Kerala. It attains maturity in the second fortnight of May, the period when the South West monsoon sets in the State. This results in hampering the quality of the fruits due to severe incidence of fruit fly and anthracnose disease caused by Colletotrichum gloeosporioides, which occurs as a latent infection during storage. This is further compounded by market gluts and huge post harvest losses, which are recurring phenomena in the State. 'Neelum', being the last variety to attain maturity in Kerala, extension of shelf life and maintenance of quality are of utmost significance to make the fruits available in the markets of the State, Hence, the present investigation was carried out with the view of extending the shelf life of mango cv. 'Neelum' and also, to maintain its quality during post harvest handling.

\section{Materials and Methods \\ Post harvest handling}

Mango fruits grown in the orchard of the College of Agriculture, Vellanikkara, Kerala Agricultural University, were harvested 110 days after fruit set and were quickly transported in plastic crates to the laboratory under the Department of Post Harvest Technology, College of Agriculture. The pedicels were clipped to retain $1 \mathrm{~cm}$ length of the stalk. The fruits were immediately subjected to desapping (drainage of exuding sap from the clipped pedicel) by keeping the fruits on news paper for $10 \mathrm{~min}$. This was followed by sorting, to remove the damaged and malformed fruits. The fruits were then sanitized by treatment with 100 ppm chlorine, followed by dipping in $1 \%$ alum solution for $3 \mathrm{~min}$. The sanitized fruits were then subjected to destaining (to avoid sap injury) by gently rubbing the surface of the fruits with foam dipped in dilute detergent solution. The destained fruits were then dipped in clean water to remove traces of detergent from the fruit surface. After destaining, the fruits were immersed in a wax solution, 'Nipro Fresh MTS40' @ 5 \% (Nipro-Fresh is an organic formulation, eco-friendly, non-ammonia based wax coating for use on fruits and vegetables that are intended to be stored in cold storage or are transported over long distances

(c) Gomez et al (2021). This is an open-access article distributed under the terms of the Creative Commons Attribution License, which permits unrestricted use, distribution and reproduction in any medium, provided the original author and source are credited (https://creativecommons.org/licenses/by/4.0/). 
\{Nipro Technologies LLC, Spokane, Washington\} (Manufacturer and Supplier: Nipro Technologies Ltd, Panchkula, Haryana, India)) in combination with the fungicide, Benfil (Carbendazim 50 WP) @ $0.1 \%$ for 5 min. [Post harvest treatment of apples, banana, citrus, mangoes, pears etc. with Carbendazim has been approved by Australian Pesticides and Veterinary Medicines Authority (PO Box. E 240, Kingston Act, 2604, Australia). The ICAR- National Research Centre for Banana, Trichy has also approved the use of Carbendazim (Bavistin) for post harvest treatment in banana. However, the wax and fungicide can be removed before consumption by soaking the fruits in lukewarm water alone or water containing vinegar or baking soda for $5 \mathrm{~min}$ and finally washing the fruits in clean water. Though acute toxicity of fungicides to humans is generally considered to be low, but can be irritating to skin and eyes. Consumption of excess Carbendazim can cause throat irritation, sneezing and coughing]. The treated fruits were then air dried under fan to remove excess moisture from the surface. These fruits were subsequently precooled at $12-13^{\circ} \mathrm{C}$, for $8 \mathrm{hr}$. This was followed by over-wrapping of four fruits of about 200 gm each, loosely on a tray made of areca nut leaf sheath with polyolefin film of $25 \mu$ thickness with an impulse sealer and then passing it through the tunnel of the shrink wrapping machine maintained at $120^{\circ} \mathrm{C}$ for 10 seconds, resulting in a consumer pack in which four mangoes on areca nut leaf sheath tray, which was tightly wrapped with the polyolefin film. These consumer packs of mangoes were subsequently held under two storage conditions viz. Ambient temperature $\left[30-32{ }^{\circ} \mathrm{C}\right.$ (maximum) and $18-20{ }^{\circ} \mathrm{C}$ (minimum) with 85-90 \% RH] and cool chamber (12$13{ }^{\circ} \mathrm{C}$ and $85-90 \% \mathrm{RH}$ ) along with the unwrapped samples. The fruits without wax treatment and shrink wrapping, under ambient and cool chamber storage, formed the control samples. The experiment consisted of six treatments viz. T1- unwrapped fruits without waxing stored under ambient conditions, T2unwrapped fruits without waxing stored in cool chamber, T3-waxed fruits stored under ambient conditions, T4- waxed fruits stored in cool chamber, T5- waxed fruits with shrink wrapping under ambient conditions and T6- waxed fruits with shrink wrapping stored in cool chamber.

\section{Quality characteristics}

Physiological loss in weight (PLW): PLW was calculated as cumulative per cent loss in weight from the initial fruit weight before storage and the loss in weight recorded on the day of observation during storage under ambient and cool chamber conditions.

\section{Respiration rate}

An oxygen/carbon dioxide analyser was used for determining the rate of respiration of the samples (Model- Dansensor, CheckPoint $\mathrm{O}_{2} / \mathrm{CO}_{2}$, Denmark). A digital display provided the level of carbon dioxide liberated by the samples. The results were expressed in percentage of $\mathrm{CO}_{2}$ accumulated in the head space of the sample.

\section{Shelf life}

Mango, being a climacteric fruit, the day on which the fruits became unmarketable was determined by taking into consideration the respiratory peak of the fruits in the various treatments and the subsequent reduction in firmness.

\section{Firmness}

The firmness of fruits during storage was determined by a digital fruit firmness tester (Vaiseshika, Model6003E, India), after removing a slice of the rind of the fruit along with a thin portion of the pulp, followed by insertion of the plunger of the tester into the fruit. The values were expressed as force required (in $\mathrm{kg}$ ) to complete penetration $(1 \mathrm{~cm})$.

\section{Total Soluble Solids (TSS)}

Estimation of TSS was done by a digital refractometer (Atago, Japan) and the results were expressed in per cent degree Brix.

\section{Titratable acidity}

Titratable acidity of the fruits was estimated by titrating a known weight of the sample against $0.1 \mathrm{~N}$ $\mathrm{NaOH}$ solution using phenolphthalein as an indicator. The acidity was calculated and expressed as percent citric acid (2).

\section{Ascorbic acid}

Ascorbic acid was determined by titrating known weight of sample with 2, 6-dichlorophenol indophenol dye, using metaphosphoric acid as stabilizing agent (2).

\section{Total phenols}

Estimation of total phenols was carried out with Folin-Ciocalteau reagent. Phenols react with phosphomolybdic acid in alkaline medium and produce a blue coloured complex (Molybdenum blue) (3). The optical density values were recorded at 650 nm (UV-Visible 1800 spectrophotometer, Shimadzu, Kyoto, Japan).

\section{Total carotenoids}

Determination of total carotenoids was done by extraction with acetone and petroleum ether (4). The optical density values were measured at $452 \mathrm{~nm}$ (UVVisible 1800 spectrophotometer, Shimadzu, Kyoto, Japan).

\section{Statistical analysis}

The experiment was laid out in the Complete Randomized Design (CRD) and the data gathered was statistically analysed using WASP (Web Agriculture Statistical Package).

\section{Results and Discussion}

Surface coating and shrink-wrap packaging were effective in prolonging the shelf life of mango fruits of cv. 'Neelum' and also had considerable advantage on maintaining the quality attributes of the fruits.

\section{Physiological loss in weight (PLW)}

PLW showed an upward trend in all the treatments during storage (Fig. 1). Surface coating of fruits with Nipro Fresh resulted in significant reduction in weight loss under ambient and low temperature storage. PLW value was the lowest in the fruits subjected to wax coating followed by shrink-wrap packaging and subsequently held in cool chamber, throughout storage. Weight loss in fruit without surface coating and shrink wrapping, stored under ambient conditions was the highest (24.3\%), after 9 
days of storage while it was only (11.2 \%) in the fruits subjected to the combined treatment of wax coating and shrink-wrap packaging, followed by holding in cool chamber, after 54 days of storage. Surface coating and shrink-wrap packaging may have resulted in the passive modification of atmospheric gases surrounding the produce, leading to accumulation of higher levels of $\mathrm{CO}_{2}$. This, along with low temperature storage might have reduced the metabolic activities of the fruits, leading to significant reduction in weight loss. These results are in

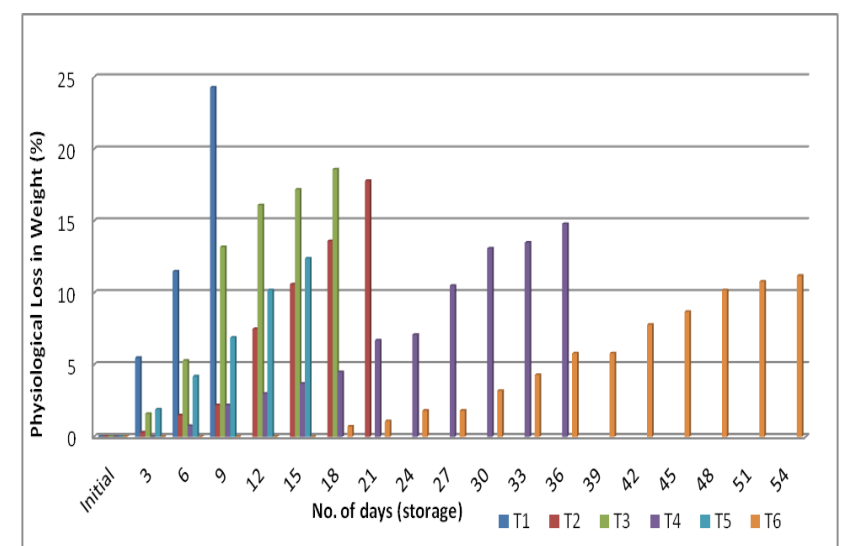

Fig. 1. Effect of surface coating and shrink-wrap packaging on physiological loss in weight (\%) of mango cv. 'Neelum'.

conformity with those reported by (5) in 'Moovandan' mangoes treated with bee wax coating followed by modified atmosphere storage. Such effects due to wax coating could also happen due to blockage of lenticels and / or stomata (6). Individual shrink wrapping resulted in 4 to 5 times reduction in weight loss in 'Alphonso' and 9 to 10 times in 'Banganapalli' cultivars of mango as compared to non-wrapped fruits (7).

\section{Respiration rate}

Rate of respiration increased gradually in all the treatments, followed by a 'respiratory peak', which is a typical character as in all 'climacteric' fruits (Fig. 2). The initial $\mathrm{CO}_{2}$ concentration in the head space of the samples ranged between 0.1 to $0.2 \%$. However, the rate of increase was significantly lower in the fruits subjected to wax coating and shrink wrapping, during storage. Further, storage in cool chamber also reduced the rate of respiration, irrespective of the treatments. Fruits subjected to waxing, followed by shrink-wrap packaging and subsequently stored in cool chamber recorded the lowest rate of respiration throughout storage and fruits in this treatment took 51 days to attain the 'respiratory peak' while the unwrapped fruits stored under ambient conditions reached the 'respiratory peak' after 9 days of storage. Fruits held under ambient conditions reached 'respiratory peak' earlier compared to their counterparts held in cool chamber, irrespective of the treatments. Surface coating followed by shrink wrapping may have acted as barriers to $\mathrm{O}_{2}$ influx and the resultant modification of atmosphere due to higher levels of $\mathrm{CO}_{2}$ may have reduced the respiratory activity. Reduction in respiratory activity of 'Moovandan' mango due to bee wax coating and modified atmosphere packaging was also reported (5). Similar findings were also reported in mango (8).

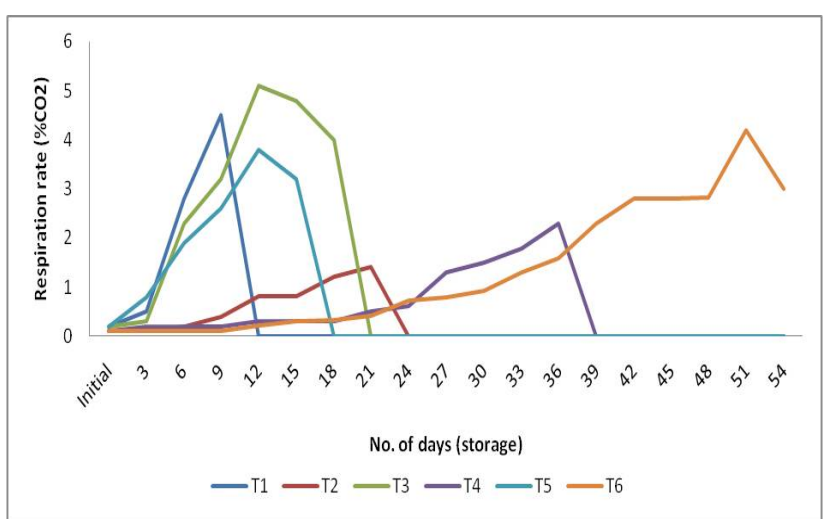

Fig. 2. Effect of surface coating and shrink-wrap packaging on respiration rate $\left(\% \mathrm{CO}_{2}\right)$ of mango cv. 'Neelum'.

T1-Unwrapped (ambient storage); T2-Unwrapped (cold storage); T3-Waxed (ambient storage); T4-Waxed (cold storage); T5-Waxed and shrink wrapped (ambient storage); T6- Waxed and shrink wrapped (cold storage).

Further, storage at low temperature may also have retarded the metabolic activity of the fruits. Higher respiratory activity of mango cvs. 'Alphonso' and 'Banganapalli' under ambient conditions was also reported (9).

\section{Shelf life}

Surface coating of mango with Nipro Fresh, followed by shrink-wrap packaging and subsequent storage at low temperature prolonged shelf life of the fruits significantly compared to the control samples. Longest shelf life of 54 days was recorded in the fruits coated with wax, followed by shrink-wrap packaging and subsequent storage in cool chamber while the shortest (9 days) was observed in the uncoated and unwrapped fruits stored under ambient conditions (Fig. 3). However, surface coating of the fruits in combination with shrink-wrap packaging in trays made of arecanut leaf sheath and subsequent storage under ambient conditions was not beneficial in extending shelf life. This was mainly due to condensation and accumulation of moisture inside the packaged samples stored under ambient conditions and absorption of moisture by the trays made of arecanut leaf sheath, which resulted in the proliferation of the anthracnose disease causing fungus Colletotrichum gloeosporioides. This may be due to higher rates of transpiration in the wrapped samples stored under ambient conditions as air can hold more moisture at higher temperatures and the polymeric film acting as a barrier to the loss of moisture in the form of vapour. Condensation of water in modified atmosphere packaged bell peppers and mangoes was reported (10). Higher decay of $48.33 \%$ was reported in pear cv. 'Nashpati', in tray over-wrapped with heat shrinkable film as compared to $30.0 \%$ in individual fruit wrapping (11). However, fruits coated with wax, followed by shrink-wrap packaging extended shelf life significantly at low temperature, compared to all other treatments. This may be due to the lower metabolic activity induced due to passive modification of atmosphere through waxing and shrink wrapping. Storage in cool chamber may have further reduced the respiratory activity. This finding is in consonance with those earlier studies reported in 'Alphonso' (12) and in 'Alphonso' and 'Banganapalli' mangoes (7). 


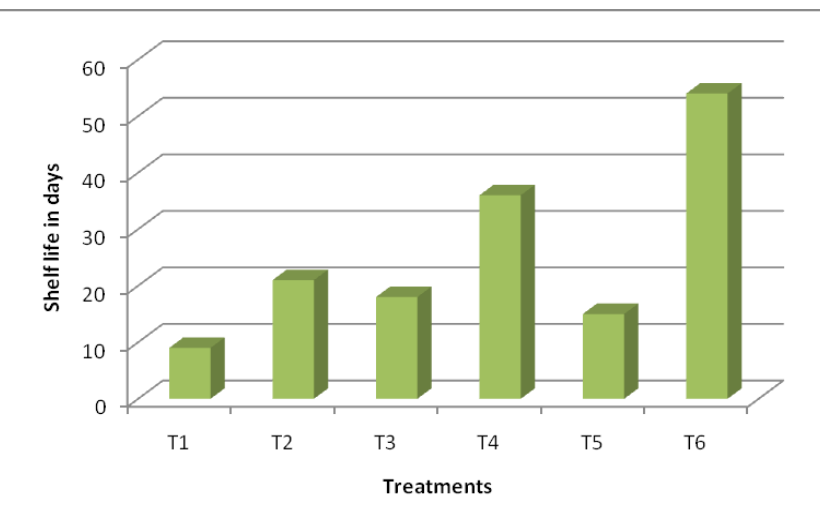

Fig. 3. Effect of surface coating and shrink-wrap packaging on shelf life (days) of mango cv. 'Neelum'.

T1-Unwrapped (ambient storage); T2-Unwrapped (cold storage); T3-Waxed (ambient storage); T4-Waxed (cold storage); T5-Waxed and shrink wrapped (ambient storage); T6- Waxed and shrink wrapped (cold storage).

\section{Fruit firmness}

Firmness of the fruits at the time of harvest was 0.87 $\mathrm{kgcm}^{-2}$ and all the treatments showed a steady decline in firmness during storage (Fig. 4). Surface coating with Nipro Fresh alone and combined treatment of wax along with shrink-wrap packaging of mango fruits of cv. 'Neelum' retained significantly higher levels of firmness under both ambient and low temperature storage, compared to the uncoated and unwrapped fruits (control). Storage in cool chamber resulted in higher retention of firmness compared to the samples held under ambient conditions. Higher retention of firmness due to wax treatment may due to reduction in transpiration rates as a result of blockage of lenticels and/ or stomata. Significant reduction in fruit firmness of egg plant due to Carnauba wax treatment and subsequent packaging in polypropylene pouches, compared to the

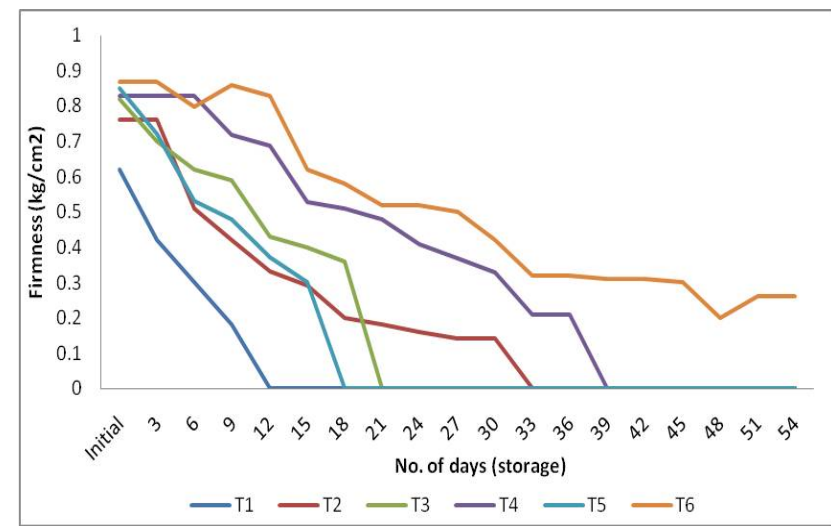

Fig. 4. Effect of surface coating and shrink-wrap packaging on firmness $\left(\mathrm{kg} \mathrm{cm}^{-1}\right)$ of mango cv. 'Neelum'.

T1-Unwrapped (ambient storage); T2-Unwrapped (cold storage) T3-Waxed (ambient storage); T4-Waxed (cold storage); T5-Waxed and shrink wrapped (ambient storage); T6- Waxed and shrink wrapped (cold storage).

unpackaged fruits (13). Further, combined treatment of mango fruits with wax and shrink-wrap packaging may have modified the atmospheric gases surrounding the produce leading to reduction in metabolic activities, particularly solubilisation of proto pectin into pectin. This solubilisation of proto pectin was further reduced by storage at low temperature due to retarded activity of pectin degrading enzymes like pectin methyl esterase and polygalacturonase. These results are in conformity with those reported in 'Alphonso' mangoes (12).

\section{Total soluble solids (TSS)}

Total soluble solids of mango fruits rose in all the samples, irrespective of treatments and storage conditions (Fig. 5). However, wax coating and shrinkwrap packaging, separately and in combination resulted in lower levels of TSS. Fruits stored under ambient conditions retained significantly higher levels of TSS compared to low temperature storage. TSS content rose to $14.0^{\circ}$ Brix after 9 days of storage in the control samples stored under ambient conditions, whereas it was $16.0^{\circ}$ Brix, after 54 days in the fruits coated with wax, followed by shrink-wrap packaging and held in cool chamber. Rise in TSS content of fruits during storage may be due to conversion of starch into sugars. Lower levels of TSS in wax coated and shrink-wrapped fruits may be due to lower rates of metabolic activity. Further, storage at low temperature may have retarded the activity of amylase enzyme involved in the conversion of starch to sugars. Similar findings were also reported (7) in 'Alphonso' and 'Banganapalli' mangoes subjected to individual shrink wrapping. Lower levels of TSS due to combined treatment of bee wax and LDPE packaging was reported in 'Moovandan’ mangoes (5).

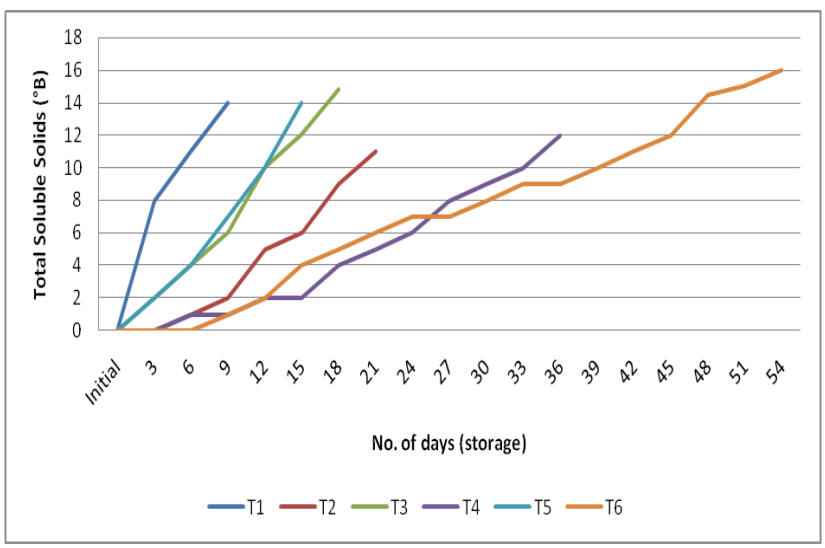

Fig. 5. Effect of surface coating and shrink-wrap packaging on total soluble solids ('Brix) of mango cv. 'Neelum'.

T1-Unwrapped (ambient storage); T2-Unwrapped (cold storage); T3-Waxed (ambient storage); T4-Waxed (cold storage); T5-Waxed and shrink wrapped (ambient storage); T6- Waxed and shrink wrapped (cold storage).

\section{Titratable acidity}

The initial tiratable acidity of mango cv. 'Neelum' was $0.92 \%$ (Table 1). A downward trend in titratable acidity was observed in all the samples throughout storage. Fruits coated with wax, followed by shrink wrapping retained higher levels of acidity compared to the uncoated and unwrapped samples. Fruits held in cool chamber had higher levels of acidity than those stored under ambient conditions. Titratable acidity declined to $0.28 \%$ in the uncoated and unwrapped fruits after one week of storage under ambient conditions, while it was $0.24 \%$ in the wax coated fruits subjected to shrink-wrap packaging and subsequently stored at low temperature, after 54 days. Decrease in titratable acids during storage may 
be attributed to utilization of organic acid in pyruvate decarboxylation reaction occurring during the ripening process of fruits (14). Retention of higher levels of acidity in the waxed fruits subjected to shrink-wrap packaging may be due to lower rates of biochemical reactions in these samples. Further, storage at low temperature may also have retarded the rate of metabolic activities. Retention of higher ascorbic acid retention were also reported in individually shrink wrapped 'Alphonso' and 'Banganapalli' mangoes (7).

\section{Total phenols}

Mango fruits of cv.Neelum had an initial total phenol content of $85.0 \mathrm{mg} 100 \mathrm{~g}^{-1}$ (Table 3). Total phenols in all the samples fell with the advancement of storage

Table 1. Effect of surface coating and shrink-wrap packaging on titratable acidity (\%) of mango cv. 'Neelum'

\begin{tabular}{|c|c|c|c|c|c|c|c|c|}
\hline Treatments & Initial & 1st week & 2nd week & 3rd week & 4th week & 5th week & 6th week & 7th week \\
\hline $\mathrm{T} 1$ & 0.92 & $0.28^{*}$ & 0.00 & 0.00 & 0.00 & 0.00 & 0.00 & 0.00 \\
\hline $\mathrm{T} 2$ & 0.92 & 0.51 & 0.49 & $0.21^{*}$ & 0.00 & 0.00 & 0.00 & 0.00 \\
\hline T3 & 0.92 & 0.75 & $0.42^{*}$ & 0.00 & 0.00 & 0.00 & 0.00 & 0.00 \\
\hline $\mathrm{T} 4$ & 0.92 & 0.76 & 0.56 & 0.28 & $0.21^{*}$ & 0.2 & 0.00 & 0.00 \\
\hline T5 & 0.92 & 0.45 & $0.21^{*}$ & 0.00 & 0.00 & 0.00 & 0.00 & 0.00 \\
\hline T6 & 0.92 & 0.64 & 0.56 & 0.28 & 0.28 & 0.27 & 0.24 & $0.24^{*}$ \\
\hline $\mathrm{CV}$ & 1.087 & 1.77 & 2.456 & 5.51 & 7.07 & 7.37 & 10.206 & 10.206 \\
\hline CD (5\%) & NS & 0.018 & 0.016 & 0.013 & 0.01 & 0.01 & 0.007 & 0.007 \\
\hline
\end{tabular}

NS-Non-significant; *Unmarketable; T1-Unwrapped (ambient storage); T2-Unwrapped (cold storage); T3-Waxed (ambient storage); T4Waxed (cold storage); T5-Waxed and shrink wrapped (ambient storage); T6- Waxed and shrink wrapped (cold storage)

levels of acidity in Nipro Fresh coated kinnow mandarin was also reported (15). Similar trends in titratable acidity of individually shrink wrapped 'Alphonso' and 'Banganapalli' mangoes were also reported (7).

\section{Ascorbic acid}

Initial ascorbic acid content of mango cv. 'Neelum' was $72.0 \mathrm{mg}^{100 \mathrm{~g}^{-1}}$ (Table 2). Ascorbic acid content showed a downward trend throughout storage. However, fruits coated with Nipro Fresh and subjected to shrink-wrap packaging retained significantly higher levels of ascorbic acid, under ambient and low temperature conditions, compared to the uncoated and unwrapped samples under both storage conditions. Ascorbic acid content of uncoated and unwrapped fruits under ambient conditions declined to $28.86 \mathrm{mg}^{100 \mathrm{~g}^{-1}}$ after one week of storage, while the fruits coated with Nipro Fresh, followed by shrink-wrapping held at cool chamber retained 45.0 mg100g-1, after seven weeks. Higher ascorbic acid content in waxed fruits followed by shrink wrapping may be due to the lower rates of respiration in these samples induced by low permeability to oxygen and subsequent retardation in the activity of oxidative enzymes responsible for ascorbic acid degradation, compared to the uncoated and unwrapped fruits. Storage of fruits in cool chamber may have further repackaging held in cool chamber retained 45.0 mg $100 g^{-1}$, after seven weeks. Higher retention of vitamin $C$ in cherries and strawberries coated with chitosan and chitooligosaccharide was reported (16) during refrigerated storage. Similar trends in period. However, Nipro Fresh coated fruits, separately and in combination with shrink-wrap packaging retained significantly higher levels of phenols. Further, storage at low temperature also prevented the loss of phenols. Total phenols in the uncoated and unwrapped samples (control) fell to $60.0 \mathrm{mg} 100 \mathrm{~g}^{-1}$, after one week of storage under ambient conditions, while the fruits coated with Nipro Fresh, followed by shrink wrapping and stored in cool chamber retained $50.0 \mathrm{mg}^{100 \mathrm{~g}^{-1}}$, after seven weeks. Decline in phenols with the advancement in maturity may be due to its polymerization to insoluble compounds, resulting in a reduction in astringency in the fruits. Fall in phenolic compounds during storage and ripening was reported in 'Hom Thong' banana (17). Higher retention of phenols in the waxed and wrapped fruits may be due to lower rates of biochemical reactions in these fruits. Storage at low temperature may have also retarded the degradation of phenols due to reduction in the activity of the enzyme, polyphenol oxidase. Similar trends were reported in 'Mas' banana stored in polybags (18).

\section{Total carotenoids}

Mango cv. 'Neelum' had a total carotenoid content of $0.2 \mathrm{mg} 100 \mathrm{~g}^{-1}$ (Table 4) at the time of harvest. The total carotenoid content rose with the advancement of maturity during storage. Significantly higher levels of carotenoids were seen in the samples stored under ambient conditions. Fruits held in cool chamber retained significantly lower levels of carotenoids, irrespective of treatments. Fruits coated with Nipro

Table 2. Effect of surface coating and shrink-wrap packaging on ascorbic acid (mg100g ${ }^{-1}$ ) of mango cv. 'Neelum'

\begin{tabular}{|c|c|c|c|c|c|c|c|c|}
\hline Treatments & Initial & 1st week & 2nd week & 3rd week & 4th week & 5th week & 6 th week & 7th week \\
\hline $\mathrm{T} 1$ & 72 & $28.86 *$ & 0.00 & 0.00 & 0.00 & 0.00 & 0.00 & 0.00 \\
\hline $\mathrm{T} 2$ & 72 & 50 & 57.6 & $57.6^{*}$ & 0.00 & 0.00 & 0.00 & 0.00 \\
\hline T3 & 72 & 52 & $62.4^{*}$ & 0.00 & 0.00 & 0.00 & 0.00 & 0.00 \\
\hline $\mathrm{T} 4$ & 72 & 65 & 67.2 & 67.2 & 51.6 & $41.6^{*}$ & 0.00 & 0.00 \\
\hline $\mathrm{T} 5$ & 72 & 57.6 & $38.4^{*}$ & 0.00 & 0.00 & 0.00 & 0.00 & 0.00 \\
\hline T6 & 72 & 60 & 67.2 & 67.2 & 63.5 & 55.3 & 47 & $45^{*}$ \\
\hline CD (5\%) & NS & 1.626 & 1.624 & 1.258 & 1.027 & 1.027 & 0.726 & 0.726 \\
\hline
\end{tabular}

NS-Non-significant; *Unmarketable; T1-Unwrapped (ambient storage); T2-Unwrapped (cold storage); T3-Waxed (ambient storage); T4-

Waxed (cold storage); T5-Waxed and shrink wrapped (ambient storage); T6- Waxed and shrink wrapped (cold storage) 
Table 3. Effect of surface coating and shrink-wrap packaging on total phenols (mg100g $\left.{ }^{-1}\right)$ of mango cv. 'Neelum'

\begin{tabular}{ccccccrrrr}
\hline Treatments & Initial & 1st week & 2nd week & 3rd week & 4th week & 5th week & 6th week & 7th week \\
\hline $\mathrm{T} 1$ & 85 & $60^{*}$ & 0.00 & 0.00 & 0.00 & 0.00 & 0.00 & 0.00 \\
\hline $\mathrm{T} 2$ & 85 & 80 & $75^{*}$ & $65^{*}$ & 0.00 & 0.00 & 0.00 & 0.00 \\
\hline $\mathrm{T} 3$ & 85 & 65 & $55^{*}$ & 0.00 & 0.00 & 0.00 & 0.00 & 0.00 \\
\hline $\mathrm{T} 4$ & 85 & 80 & 75 & 70 & 65 & $45^{*}$ & 0.00 & 0.00 \\
\hline $\mathrm{T} 5$ & 85 & 75 & $65^{*}$ & 0.00 & 0.00 & 0.00 & 0.00 & 0.00 \\
\hline $\mathrm{T} 6$ & 85 & 85 & 85 & 80 & 75 & 60 & 55 & $50^{*}$ \\
\hline $\mathrm{CV}$ & 1.176 & 1.348 & 1.543 & 1.973 & 2.474 & 3.299 & 4.454 & 4.899 \\
\hline $\mathrm{CD}(5 \%)$ & $\mathrm{NS}$ & 1.779 & 1.624 & 1.258 & 1.027 & 1.027 & 0.726 & 0.726 \\
\hline
\end{tabular}

NS-Non-significant; *Unmarketable; T1-Unwrapped (ambient storage); T2-Unwrapped (cold storage); T3-Waxed (ambient storage); T4Waxed (cold storage); T5-Waxed and shrink wrapped (ambient storage); T6- Waxed and shrink wrapped (cold storage)

Table 4. Effect of surface coating and shrink-wrap packaging on total carotenoids(mg100g $\left.{ }^{-1}\right)$ of mango cv. 'Neelum'

\begin{tabular}{cccccccccc}
\hline Treatments & Initial & 1st week & 2nd week & 3rd week & 4th week & 5th week & 6th week & 7th week \\
\hline $\mathrm{T} 1$ & 0.2 & $1.680^{*}$ & 0.00 & 0.00 & 0.00 & 0.00 & 0.00 & 0.00 \\
\hline $\mathrm{T} 2$ & 0.2 & 0.380 & 0.960 & $1.060^{*}$ & 0.00 & 0.00 & 0.00 & 0.00 \\
\hline $\mathrm{T} 3$ & 0.2 & 0.600 & $1.850^{*}$ & 0.00 & 0.00 & 0.00 & 0.00 & 0.00 \\
\hline $\mathrm{T} 4$ & 0.2 & 0.218 & 0.505 & 0.820 & 1.040 & $1.380^{*}$ & 0.00 & 0.00 \\
\hline $\mathrm{T} 5$ & 0.2 & 0.390 & $0.820^{*}$ & 0.00 & 0.00 & 0.00 & 0.00 & 0.00 \\
\hline $\mathrm{T} 6$ & 0.2 & 0.217 & 0.501 & 0.810 & 0.940 & 0.980 & 1.070 & $1.210^{*}$ \\
\hline $\mathrm{CV}$ & 0.5 & 1.719 & 5.384 & 9.197 & 1.750 & 1.468 & 2.289 & 2.024 \\
\hline $\mathrm{CD}(5 \%)$ & $\mathrm{NS}$ & 0.018 & 0.074 & 0.073 & 0.01 & 0.01 & 0.007 & 0.007 \\
\hline
\end{tabular}

NS-Non-significant; *Unmarketable; T1-Unwrapped (ambient storage); T2-Unwrapped (cold storage); T3-Waxed (ambient storage); T4Waxed (cold storage); T5-Waxed and shrink wrapped (ambient storage); T6- Waxed and shrink wrapped (cold storage)

Fresh in combination with shrink-wrap packaging and held in cool chamber retained the lowest levels of carotenoids throughout storage. Carotenoid content of the uncoated and unwrapped samples rose to $1.68 \mathrm{mg}^{100 \mathrm{~g}^{-1}}$, after one week of storage whereas the fruits coated with Nipro Fresh, followed by shrink-wrap packaging and held in cool chamber retained only $1.21 \mathrm{mg} 100 \mathrm{~g}^{-1}$, after seven weeks. Higher levels of carotenoids in the samples stored under ambient conditions may be due to higher rates of metabolic activities at higher temperature. Reduction in biochemical reactions in the wax coated fruits in combination with shrink wrapping and low temperature storage may have led to lower levels of carotenoids in these samples. Retention of significantly lower levels of carotenoids in individually shrink wrapped 'Alphonso' mango with LDPE film was also reported (7). Elevated $\mathrm{CO}_{2}$ concentration inhibits ethylene synthesis which, in turn, influences chlorophyll breakdown. Low levels of $\mathrm{O}_{2}$ also inhibit ethylene production (19).

\section{Conclusion}

The findings of the study reveal that the fruits of mango cv. 'Neelum', when coated with the wax Nipro Fresh, followed by shrink wrap packaging with polyolefin film of $25 \mu$ thickness in trays made of areca nut leaf sheath is an ideal technique for extending shelf life of this mango cultivar. Harvesting the fruits at 110 days after fruit set, followed by sanitization treatments with chlorine and alum, and then dipping in the wax Nipro Fresh containing Carbendazim and then precooling at $12-13{ }^{\circ} \mathrm{C}$ for 8 hours and subjecting the precooled fruits to shrinkwrap packaging with polyolefin film in areca nut leaf sheath trays and subsequently holding these fruits in a cool chamber at $12-13{ }^{\circ} \mathrm{C}$ and $85-90 \%$ relative humidity, could prolong the shelf life of the fruits up to 54 days. This technique can be adopted as a viable practice of post harvest handling to extend the availability and to maintain quality of mango cv. 'Neelum', which is the last commercial variety to attain maturity in the Indian State of Kerala, coinciding with the onset of South West monsoon which adversely affects the fruit quality. Occurrence of traces of the wax and fungicides in the flesh of fruit needs to be studied in the future experiments.

\section{Acknowledgements}

The study was carried out with the funds received from Kerala State Planning Board through the Directorate of Research, Kerala Agricultural University (Grant No. R8/64430/2019).

\section{Authors' contributions}

SG conceived and carried out the experiment with the supervision of MJ. SJ, DJ and KS assisted in the analysis of quality parameters and statistical analysis. The manuscript was written and edited by SG.

\section{Conflict of interests}

Authors do not have any conflict of interests to declare.

\section{References}

1. Farm Guide. Farm Information Bureau, Department of Agricultural Development and Farmers' Welfare, Kerala Government.2019; pp. 291.

2. AOAC, [Association of Official Agricultural Chemists] Official methods of analysis of AOAC International (16th ed.). Association of Official Agricultural Chemists, Washington, D. C. 1998; pp. 899.

3. Asami DK, Hong YJ, Barrett DM, Mitchell AE. Comparison of the total phenolic and ascorbic acid content of freeze-dried 
and air dried marionberry, strawberry and corn grown using conventional, organic and sustainable agricultural practices. Journal of Agricultural and Food Chemistry. 2003;51:1237-41. https://doi.org/10.1021/jf020635c

4. RangannaS. Handbook of analysis and quality control for fruit and vegetable products (2nd ed). Tata McGraw Hill Publishing Company Limited, New Delhi. 1997; pp. 1112.

5. Amulya PR, Sudheer KP, Rifna EJ, Sreesha KR, Nusaiba C. Effect of edible wax coating and MAP on the quality of mango during storage. International Journal of Agricultural Science and Research. 2016;6:13-18.

6. Dhalla R, Hanson SW. Effect of permeable coatings on the storage life of fruits. International Journal of Food Science. 1988;23:107-12. 2621.1988.tb00556.x

7. SudhakarRao DV, Shivashankara KS. Individual shrink wrapping extends the storage life and maintains the antioxidants of mango (cvs.'Alphonso' and 'Banganapalli') stored at $8{ }^{\circ} \mathrm{C}$. Journal of Food Science and Technology. 2015;52:4351-59. https://doi.org/10.1007/s13197-014-1468-6

8. JosephK, Aworth OC. Postharvest treatment of 'Wild' mango for improved shelf life. Food Chemistry. 1992;44:45-48. https:// doi.org/10.1016/0308-8146(92)90256-2

9. SudhakarRao DV, GopalakrishnaRao KP. Effect of controlled atmosphere conditions and pre-treatments on ripening behavior of mangoes stored at low temperature. Journal of Food Science and Technology. 2009;46:300-06.

10. Ben-Yehoshua S, Rodov V, Fishman S, Peretz J. Modified atmosphere packaging of fruits and vegetables: reducing condensation of water in bell peppers and mangoes. Acta Horticulturae. https://doi.org/10.17660/ActaHortic.1998.464.59

11. Ng Piloo, Singh SR, Messar O, Pandey AK. Shelf life extensions of pear cv. 'Nashpati' using shrink wrapping in East Siang district of Arunachal Pradesh, India. International Journal of Current Microbiology and Applied Sciences. 2018;7:1504-10. https://doi.org/10.20546/ijcmas.2018.705.176

12. NidhiRamayya, Keshavan Niranjan, Eric Duncan. Effects of modified atmosphere packaging on quality of 'Alphonso' mangoes. Journal of Food Science and Technology. 2012;49:721-28. https://doi.org/10.1007/s13197-010-0215-x

13. Sudhir Singh, PritiKhemariya, AshutoshRai, Avinash Chandra Rai, Tanmay K, Koley, Bijendra Singh. Carnauba wax-based edible coating enhances shelf life and retains quality of egg plant (Solanum melongena) fruits. LWT- Food Science and
Technology.

https://doi.org/10.1016/j.lwt.2016.08.004

2016;74:420-26

14. Echeverria E, Valich J. Enzymes of sugar and acid metabolism in stored Valencia oranges. Journal of American Society of Horticultural Science. 1989;114:445-49.

15. Mahajan BVC, DhillonWS, Mahesh Kumar.Effect of surface coatings on the quality and shelf life of kinnow fruits during storage. Journal of Postharvest Technology. 2013;1:8-15.

16. Kerch, G, Sabovics M, Kruma Z, Kampuse S, Straumite E. Effect of chitosan and chitooligosaccharide on vitamin $\mathrm{C}$ and polyphenols contents in cherries and strawberries during refrigerated storage. European Food Research and Technology. 2011;233:351-58. https://doi.org/10.1007/s00217-011-1525-6

17. Fernando HRP, Srilaong V, Pongprasert N, Boonyaritthongchai $\mathrm{P}$, Jitareerat $\mathrm{P}$. Changes in antioxidant properties and chemical composition during ripening in banana variety 'Hom Thong' (AAA group) and 'Khai' (AA group). International Food Research Journal. 2014;21:749-54.

18. Tan SC, Mohamed AA, Tan SC. The effect of $\mathrm{CO}_{2}$ on phenolic compounds during the storage of 'Mas' banana in polybags. Acta Horticulturae. 1990;269:389 https://doi.org/10.17660/ActaHortic.1990.269.50

19. Medlicott AP, Sigrist JMM, Reynolds SB, Thompson AK. Effect of ethylene and acetylene on mango fruit ripening. Journal of Applied Biology and Biotechnology. 1987;111:439-44. https:// doi.org/10.1111/j.1744-7348.1987.tb01472.x

Additional information

Peer review information: Plant Science Today thanks Sectional Editor and the other anonymous reviewers for their contribution to the peer review of this work.

Reprints and permissions information is available at

https://horizonepublishing.com/journals/index.php/PST/open_access_policy

Publisher's Note: Horizon e-Publishing Group remains neutral with regard to jurisdictional claims in published maps and institutional affiliations.

To cite this article: Gomez S, Jacob S, Joseph M, Johnson D, Sebastian K. Evaluation of surface coating and shrink- wrap packaging on shelf life and quality of mango cultivar 'Neelum'. Plant Science Today. 2021;8(3):545551. https://doi.org/10.14719/pst.2021.8.3.1192

Plant Science Today, published by Horizon e-Publishing Group, is covered by Scopus, Web of Science, BIOSIS Previews, Clarivate Analytics, etc. See https://horizonepublishing.com/journals/index.php/PST/indexing_abstracting 